22. Kyritsis AP, Bondy ML, Xiao M, et al. Germline p53 gene mutations in subsets of glioma patients. JNCI 1994;86:344349.

23. Patel A, van Meyel DJ, Mohapatra G, et al. Gliomas in families: chromosomal analysis by comparative genomic hybridization. Cancer Genet Cytogenet 1998;100:77-83.

24. van Meyel DJ, Ramsay DA, Chambers AF, Macdonald DR, Cairncross JG. Absence of hereditary mutations in exons 5 through 9 of the p53 gene and exon 24 of the neurofibromin gene in families with glioma. Ann Neurol 1994;35:120-122.

25. Watling CJ, van Meyel DJ, Ramsay DA, Macdonald DR, Cairncross JG. Loss of heterozygosity analysis of chromosomes 9,10 and 17 in gliomas in families. Can J Neurol Sci 1995;22:17-21.

26. Al-Sarraj ST. Molecular genetic analysis of non-astrocytic gliomas. Histopathology 1999;34:370-371.
27. Lander ES, Schork NJ. Genetic dissection of complex traits. Science 1994;265:2037-2048.

28. Risch N, Merikangas K. The future of genetic studies of complex diseases. Science 1996;273:1516-1517.

29. Sveinbjornsdottir S, Hicks AA, Jonsson T, et al. Familial aggregation of Parkinson's disease in Iceland. N Engl J Med 2000;343:1765-1770.

30. Lander ES, Botstein D. Homozygosity mapping: a way to map human recessive traits with the DNA of inbred children. Science 1987;236:1567-1570.

31. Esteller M, Garcia-Foncillas J, Andion E, et al. Inactivation of the DNA-repair gene MGMT and the clinical response of gliomas to alkylating agents. N Engl J Med 2000;343:1350-1354.

32. Kleihues P, Ohgaki H. Genetics of glioma progression and the definition of primary and secondary glioblastoma. Brain Pathol 1997;7:1131-1136.

\title{
Neuro/mages
}
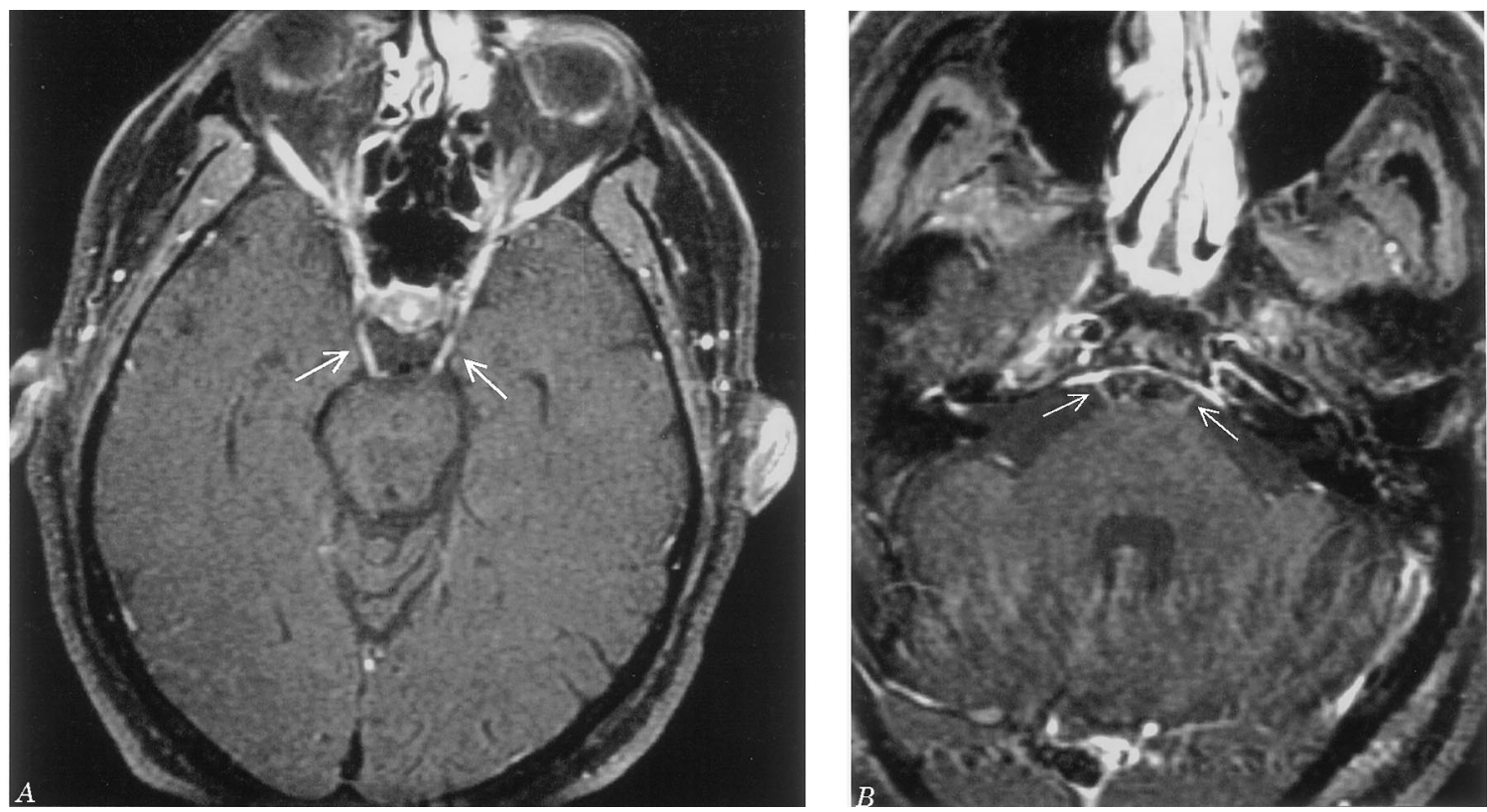

Figure. Axial sections of brain MRI after double-dose gadolinium administration. T1-weighted and fat-suppressed technique demonstrates enhancement of $3 r d(A)$, 6th (B), and 7th (not shown) cranial nerves bilaterally.

\section{Miller Fisher syndrome: MRI findings}

C.A. Garcia-Rivera, DO, D. Zhou, MD, P. Allahyari, R. Niknam, D. Dougherty, MD, J. Morgan, MD, A. Flanders, MD

A 57-year-old man presented with new-onset diplopia. This progressed to complete ophthalmoplegia, facial diplegia, and ataxic gait. Examination demonstrated bilateral 3rd, 6th, and 7th cranial neuropathies, areflexia or hyporeflexia of all deep tendon reflexes, and gait ataxia. CSF demonstrated elevated protein levels with no cells. An MRI of the brain showed enhancement of oculomotor, abducens, and facial nerves bilaterally with no brainstem abnormalities (figure). Miller Fisher syndrome (MFS) was diagnosed.

MFS is thought to be a clinical subtype of the
Guillian-Barré syndrome and is characterized by the neurologic signs of ophthalmoplegia, gait ataxia, and areflexia. Facial paresis also frequently occurs in MFS. ${ }^{1}$ Abnormal gadolinium enhancement of cranial nerves in MFS has rarely been documented in the literature..$^{2,3}$ MRI of the brain with a double dose of gadolinium may be a good confirmatory test for a diagnosis of MFS in the correct clinical setting.

1. Mori M, Kuwabara S, Fukutake T, Yuki N, Hattori T. Clinical features and prognosis of Miller Fisher syndrome. Neurology 2001;56:1104-1106.

2. Hattori M, Takada K, Yamada K, Kamomito K, Mitake S. A case of Miller Fisher syndrome with gadolinium-enhancing lesions in cranial nerves and cauda equina on MRI. Rinsho Shinkeigaku 1999;39:10541058.

3. Nagaoka U, Kato T, Kurita K, et al. Cranial nerve enhancement on three-dimensional MRI in Miller Fisher syndrome. Neurology 1996;47: 1601-1602. 


\section{Neurology}

Miller Fisher syndrome: MRI findings

C. A. Garcia-Rivera, T.D. Rozen, D. Zhou, et al.

Neurology 2001;57;1755

DOI 10.1212/WNL.57.10.1755

This information is current as of November 27, 2001

\section{Updated Information \&} Services

\section{References}

Citations

Subspecialty Collections

Permissions \& Licensing

Reprints including high resolution figures, can be found at: http://n.neurology.org/content/57/10/1755.full

This article cites 3 articles, 2 of which you can access for free at: http://n.neurology.org/content/57/10/1755.full\#ref-list-1

This article has been cited by 1 HighWire-hosted articles: http://n.neurology.org/content/57/10/1755.full\#\#otherarticles

This article, along with others on similar topics, appears in the following collection(s):

Guillain-Barre syndrome

http://n.neurology.org/cgi/collection/guillainbarre_syndrome MRI

http://n.neurology.org/cgi/collection/mri

Information about reproducing this article in parts (figures,tables) or in its entirety can be found online at:

http://www.neurology.org/about/about_the_journal\#permissions

Information about ordering reprints can be found online:

http://n.neurology.org/subscribers/advertise

Neurology ${ }^{\circledR}$ is the official journal of the American Academy of Neurology. Published continuously since 1951, it is now a weekly with 48 issues per year. Copyright. All rights reserved. Print ISSN: 0028-3878.

Online ISSN: 1526-632X.

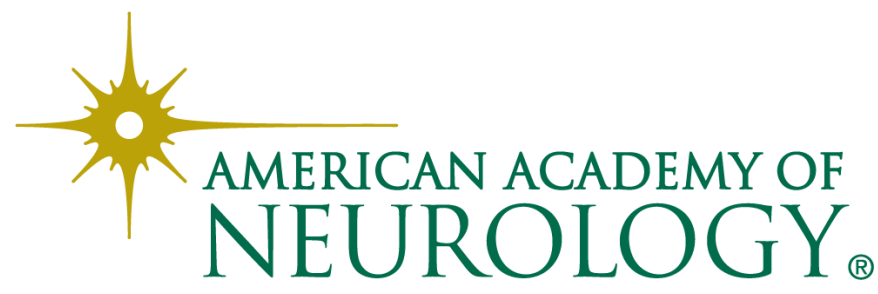

